\title{
KARAKTERISTIK SOAL LITERASI MEMBACA PADA PROGRAM PISA
}

\author{
Titik Harsiati \\ Fakultas Sastra Universitas Negeri Malang \\ email: titik.harsiati.fs@um.ac.id
}

\begin{abstract}
Abstrak
Studi Programme for International Student Assessment (PISA) bertujuan untuk mengetahui efektivitas sistem pendidikan dalam perspektif internasional dengan berfokus pada hasil asesmen Sains, Matematika, dan Literasi Membaca. Penelitian ini bertujuan menelaah karakteristik soal membaca PISA pada empat kali pelaksanaan, yaitu soal membaca sebagai bahan uji mayor 2000-2009 dan sebagai bahan uji minor 2003-2006. Penelitian ini adalah penelitian kualitatif dengan teknik analisis isi. Data yang digunakan adalah hasil PISA tahun 2000-2009. Hasil analisis menunjukkan bahwa soal literasi membaca PISA didominasi keterampilan berpikir tingkat tinggi berupa kemampuan interpretasi, refleksi, dan evaluasi. Kemampuan membaca yang diujikan adalah mengungkapkan kembali informasi, mengembangkan interpretasi dan mengintegrasikan, dan merefleksikan dan mengevaluasi teks. Soal cenderung menggunakan wacana panjang (135-630 kata) dan kalimat pertanyaan cenderung kompleks. Ragam tes yang digunakan meliputi pilihan ganda, pilihan ganda kompleks, jawaban singkat, esai tertutup, dan esai terbuka. Karakteristik konteks diklasifikasikan empat kategori, yaitu pendidikan, pekerjaan, personal, dan masyarakat. Isi kutipan bertema keselamatan keamanan diri, bermasyarakat, cara menyelesaikan pendidikan dan IPTEK, cerita personal berisi nilai moral untuk meningkatkan kualitas hidup.
\end{abstract}

Kata kunci: literasi, kemampuan membaca, sistem pendidikan, karakteristik soal

\section{THE CHARACTERISTICS OF LITERACY TEST ITEMS IN PISA}

\begin{abstract}
A study of the Program for International Student Assessment (PISA) aimed to investigate the effectiveness of the education system in an international perspective by focusing on the results of the science, mathematics, and literacy assessments. This study aimed to examine the characteristics of PISA reading test items from four administrations, namely reading as a major test in 20002009 and as a minor test in 2003-2006. This was a qualitative study using content analysis. The data were the results of PISA in 2000-2009. The results of the analysis showed that the PISA literacy test items were dominated by those measuring high-order thinking skills in the form of the ability in interpretation, reflection, and evaluation. The reading ability tested was revealing information, developing and integrating interpretation, and reflecting and evaluating texts. The test items tended to be based on long discourses (135-630 words) and the questions tended to be complex. In terms of variety, the item tests included multiple choice, complex multiple choice, short answer, closed essay, and open essay items. The characteristics of the contexts were classified into four categories, namely education, employment, personal matters, and community. The contents of the citations comprised self-safety, community, ways of completing education, and science and technology. Personal stories contained moral values to improve the quality of life.
\end{abstract}

Keywords: literacy, reading ability, educational system, characteristics of test items

90 | LITERA Volume 17, Nomor 1, Maret 2018 


\section{PENDAHULUAN}

Informasi yang akurat mengenai mutu pendidikan di Indonesia dalam mempersiapkan peserta didik untuk menjalankan kehidupan bermasyarakat di era globalisasi sangat diperlukan. Selain itu, di era globalisasi benchmarking mutu pendidikan antarnegara menjadi bagian penting dalam menentukan arah pendidikan suatu negara. Sebagai salah satu upaya benchmarking pencapaian program pendidikan nasional, Indonesia berpartisipasi dalam studi internasional Programme for International Student Assessment (PISA). PISA merupakan studi yang dikoordinasikan oleh negara-negara OECD (Organisation for Economic Cooperation and Development).

Studi PISA bertujuan melihat efektivitas sistem pendidikan dengan perspektif internasional. Selama 12 tahun mengikuti PISA prestasi Indonesia masih di bawah rata-rata skor literasi membaca internasional. Pada tahun 2000 rata-rata skor literasi membaca siswa Indonesia sebesar 371. Pada tahun 2003 rata-rata skor literasi membaca siswa Indonesia sebesar 382. Pada tahun 2006 rata-rata skor literasi membaca siswa Indonesia sebesar 393. Pada tahun 2009 rata-rata skor literasi membaca siswa Indonesia sebesar 402. Padahal rata-rata skor minimal literasi internasional seharusnya sebesar 500 (OECD, 2009). Kemampuan literasi membaca siswa Indonesia berada pada level 2 dari 6 level yang ada. Karakteristik level 2 adalah dapat menemukan satu atau dua informasi yang dibutuhkan untuk membuat inferensi atau menghadapi beberapa kondisi. Siswa juga mampu menentukan ide pokok, memahami hubungan, mengkontruksi makna untuk inferensi.

Berdasarkan data kondisi kemampuan literasi membaca siswa Indonesia yang masih berada jauh di level bawah tersebut, dilakukan penelitian terhadap karakteristik soal membaca pada program internasional PISA pada tahun 2000 sampai tahun 2009. Dengan penelitian ini dapat diperoleh gambaran utuh karakteristik soal literasi membaca PISA.

Literasi merupakan kemampuan seseorang dalam memahami, menggunakan dan merefleksikan bacaan tertulis untuk mencapai tujuan sesuai keperluan, mengembangkan pengetahuan dan potensi, serta berpartisipasi dalam masyarakat. Literasi membaca diukur dalam hubungannya dengan: (1) format bacaan: narasi, eksposisi, dan argumentasi, formulir, tabel, atau bagan, (2) tingkat berpikir dalam proses membaca mencakup kegiatan mencari informasi, membentuk pemahaman yang luas dari teks, menginterpretasikan, merefleksi/ mengevaluasi (konten, bentuk, dan cirinya), dan (3) konteks isi kutipan dan tujuan pemilihan kutipan. Literasi membaca dilihat dari kemampuan siswa menggunakan teks tulis untuk tujuan-tujuan yang dituntut secara sosial dan berguna bagi individu untuk mengembangkan pengetahuan/potensinya. Membaca bukan decoding sederhana tetapi memadukan pemahaman dan penggunaan informasi tulis untuk tujuan-tujuan fungsional.

Literasi membaca mencakup kemampuan kognitif yang lebih luas daripada pengkodean dasar melalui pengetahuan kata per kata, tata bahasa, linguistik dan struktur teks. Literasi membaca merupakan kemampuan metakognitif yang berisi kesadaran dan kemampuan menggunakan berbagai strategi yang sesuai ketika memproses teks. PISA mendefinisikan literasi membaca sebagai sebuah pemahaman, 
menggunakan dan merefleksikan teks tertulis untuk mencapai tujuan, memperoleh pengetahuan, mengembangkan potensi dan berpartisipasi dalam masyarakat (OECD, 2006).Pengertian literasi membaca berkembang sesuai dengan perkembangan tuntutan zaman. Pada awalnya secara sederhana, literasi memiliki arti sebuah kemampuan membaca dan menulis atau melek aksara. Pada era perkembangan informasi teknologi dan globalisasi ini, literasi membaca dimaknai secara luas. Literasi membaca mencakup makna melek teknologi, berpikiran kritis, peka terhadap lingkungan sekitar, serta mampu mengaplikasikan apa yang dibaca. Kemampuan literasi membaca dalam perkembangan mutakhir berkaitan dengan kemampuan memahami secara kritis-kreatif berbagai bentuk wacana tulis yang ada dalam komunikasi nyata (Hayat, 2006).

Kemampuan literasi membaca mutakhir berkaitan erat dengan kemampuan berpikir, kemampuan bernalar, dan kreativitas yang diperlukan seseorang untuk hidup di zaman informasi. Pada zaman serba modern seorang baru bisa dikatakan memiliki kemampuan literasi jika ia sudah bisa memahami sesuatu karena membaca dan melakukan sesuatu berdasarkan pemahaman bacaannya (Hirai L. Cook: 2009). Selanjutnya dijelaskan bahwa kemampuan literasi membaca adalah kemampuan untuk memanfaatkan wacana tulis dengan memahami ciri-ciri dan kunci-kunci penanda makna untuk memprediksi, menginterpretasi, dan merekonfirmasi makna secara tepat.

Pada PISA literasi membaca mencakup pemahaman/proses berpikir tingkat tinggi yang menuntut pembaca memberikan reaksi kritis-kreatif terhadap bacaan dalam me- nemukan signifikasi, nilai, fungsi, dan hubungan isi bacaan itu dengan suatu masalah kehidupan yang lebih luas serta dampak dari masalah yang dipaparkan pengarang berpikir kritis-kreatif. Pembaca menggunakan atau mengolah berbagai jenis wacana yang ada dalam komunikasi nyata secara kritis-kreatif. (Burn, Roe, dan Roos, 2002). Alderson (2003: 3) menyatakan bahwa literasi membaca mencakup proses dan produk. Membaca sebagai proses mekanistis digolongkan sebagai membaca tingkat rendah. Membaca bukan hanya membaca informasi secara literal, tetapi membaca secara interaktif untuk mendapatkan pemahaman secara kritis-kreatif.

Teks secara garis besar dikelompokkan dua bagian yaitu teks kontinyus dan nonkontinyus. Teks berkesinambungan (kontinyus) mencakup jenis teks deskripsi (impresionistik, teknis), narasi (paparan naratif, laporan, berita), eksposisi (esai eksposisi, definisi, penjelasan, ringkasan, notulen, teks interpretasi), argumentasi (komentar, argumentasi ilmiah), instruksi (arahan, aturan). Teks nonkontinyus: berupa daftar sederhana, daftar campuran, daftar kolom, daftar jaringan, daftar kombinasi), dengan format (form, lembar info, vucer, sertfikat, iklan, bagan/ grafik, tabel dan matrik, daftar sesuatu, peta).

Studi PISA dilaksanakan setiap tiga tahun dengan penekanan yang berbedabeda. Siklus pertama tahun 2000, 2003, dan 2006, siklus kedua tahun 2009, 2012, dan 2015. Urutan penekanan domain pada setiap siklus adalah membaca, matematika, dan sains. Indonesia telah mengikuti survei PISA ini mulai tahun 2000. Jumlah negara yang berpartisipasi pada studi PISA tahun 2000 sebesar 43 negara, tahun 2003 sebesar 
41 negara, tahun 2006 sebesar 57 negara, dan tahun 2009 sebesar 65 negara.

Dengan telaah karakteristik soal literasi PISA ini diharapkan memberikan masukan dalam upaya meningkatkan kemampuan literasi membaca siswa Indonesia di masa mendatang. Lembaga terkait dapat menggunakan hasil telaah ini untuk mengembangkan bahan ajar, metode, dan sistem penilaian membaca yang sesuai agar dapat menyiapkan pengetahuan dan keterampilan siswa usia 15 tahun (akhir SMP).

Tujuan penelitian ini adalah mendeskripsikan karakteristik soal literasi membaca pada PISA 2000-2009. Secara rinci penelitian ini bertujuan mendeskripsikan (1) karakteristik jenis tingkat berpikir/ kompetensi membaca yang terdapat pada soal literasi membaca PISA tahun 2000, 2003, 2006, dan 2009, (2) karakteristik bentuk tes dan penyajian yang digunakan pada soal literasi membaca PISA tahun 2000, 2003, 2006, dan 2009, (3) karakteristik ragam konteks dan isi wacana pada kutipan soal literasi membaca PISA, (4) karakteristik kebahasaan yang digunakan pada wacana soal literasi membaca PISA tahun 2000, 2003, 2006, dan 2009, (5) proporsi tingkatan berpikir dan ragam teks pada soal membaca PISA sebagai bahan uji minor (PISA 2003 dan 2006), dan (6) proporsi tingkatan berpikir dan ragam teks pada soal membaca PISA sebagai bahan uji minor (PISA 2003 dan 2006),

\section{METODE}

Pendekatan dalam penelitian ini menggunakan metode kualitatif karena penelitian ini akan menghasilkan data deskriptif berupa kata-kata tertulis atau lisan dari orang-orang yang diamati (Seviula,
1991:3). Sumber data adalah soal literasi membaca PISA pada tahun 2000, 2003, 2006, dan 2009. Teknik analisis data menggunakan teknik analisis isi. Dengan teknik analisis isi disimpulkan karakter inferential dari pengkodean unit-unit tekstual ke dalam kategori-kategori konseptual. Dengan analisis isi disimpulkan inferensiinferensi dengan mengidentifikasi secara sistematik dan objektif karakteristik-karakteristik khusus dalam sebuah fenomena tekstual (Kinderpoff, 1993).

Wujud data dalam penelitian ini adalah paparan: (1) jenis tingkat berpikir/ aspek proses membaca yang terdapat pada soal literasi membaca PISA tahun 2000, 2003, 2006, dan 2009, (2) jenis bentuk tes yang digunakan pada soal literasi membaca PISA tahun 2000, 2003, 2006, dan 2009, (3) karakteristik ragam isi wacana dan ragam bentuk wacana pada kutipan wacana soal literasi membaca PISA, dan (4) karakteristik kebahasaan yang digunakan pada wacana soal literasi membaca PISA tahun 2000, 2003, 2006, dan 2009.

\section{HASIL DAN PEMBAHASAN Karakteristik Tingkat Berpikir pada Soal Membaca PISA}

Dari segi aspek kompetensi membaca yang diukur, soal literasi membaca PISA memiliki karakteristik berfokus pada kemampuan berpikir tingkat tinggi. Pada soal membaca PISA aspek kompetensi membaca dikategorikan tiga jenis yang mencakup: (a) kemampuan mengungkapkan kembali informasi (retrieving Information), (b) mengembangkan interpretasi (developing an interpretation), (c) merefleksikan dan mengevaluasi teks. Tingkat berpikir tingkat tinggi mendominasi keseluruhan soal membaca PISA dari tahun 2000 sampai 2009. 
Kemampuan berpikir tingkat tinggi mencakup kemampuan mengembangkan interpretasi, kemampuan merefleksi, dan kemampuan mengevaluasi teks. Di bawah ini dicontohkan soal mengungkapkan kembali informasi, mengintegrasikan/menginterpretasi, serta refleksi dan evaluasi.

\section{SI KIKIR DAN EMASNYA}

Seorang yang kikir menjual seluruh hartanya dan membeli segumpal emas yang dikuburnya di dalam sebuah lubang di samping sebuah dinding tua. Dia kemudian mengunjungi simpanannya itu setiap hari. Salah seorang anak buahnya memperhatikan hal ini dan memutuskan untuk mengintai gerak gerik si kikir. Anak buahnya ini kemudian mengetahui rahasia harta yang tersembunyi tersebut, dan mulai menggali, dan menemukan segumpal emas, dan dicurinya. Si kikir, pada kunjungan berikutnya, menemukan lubang yang sudah kosong dan mulai menariknarik rambutnya dan meraung-meraung sejadi-jadinya. Seorang tetangga, yang melihat kejadian itu dan mengetahui apa penyebabnya, kemudian berkata, "Berdoalah dan jangan bersedih, ambillah segumpal batu, dan letakkan di dalam lubang itu, dan bayangkan seolaholah emas itu masih berada di sana. Bagi kamu hal itu akan sama saja, karena sewaktu emas itu berada di sana, kamu tidak memilikinya, karena kamu sedikit pun tidak menggunakannya."

Berdasarkan bacaan di atas, dapat disusun pertanyaan-pertanyaan dengan beberapa karakteristik tingkat berpikir.

Pertama, tipe pertanyaan untuk mengukur kemampuan menemukan kembali informasi dari teks, seperti contoh soal di bawah ini.

Bacalah pernyataan berikut dan berilah nomor sesuai dengan urutan kejadian di dalam bacaan.

Si kikir memutuskan untuk menggunakan seluruh uangnya untuk membeli segumpal emas.

Seseorang mencuri emas si kikir.

Si kikir menggali lubang dan menyembunyikan hartanya di sana.

Tetangga si kikir menyuruhnya untuk menggantikan emas itu dengan sebuah batu.

Kedua, tipe pertanyaan mengintegrasikan dan menginterpretasikan. Pembaca dituntut mengembangkan interpretasi dengan mengintegrasikan berbagai pengetahuan dan menghubungkan rincian cerita dengan ide utama, seperti contoh soal di bawah ini.

Berikut ini adalah percakapan antara dua orang yang membaca cerita "Si kikir dan emasnya.

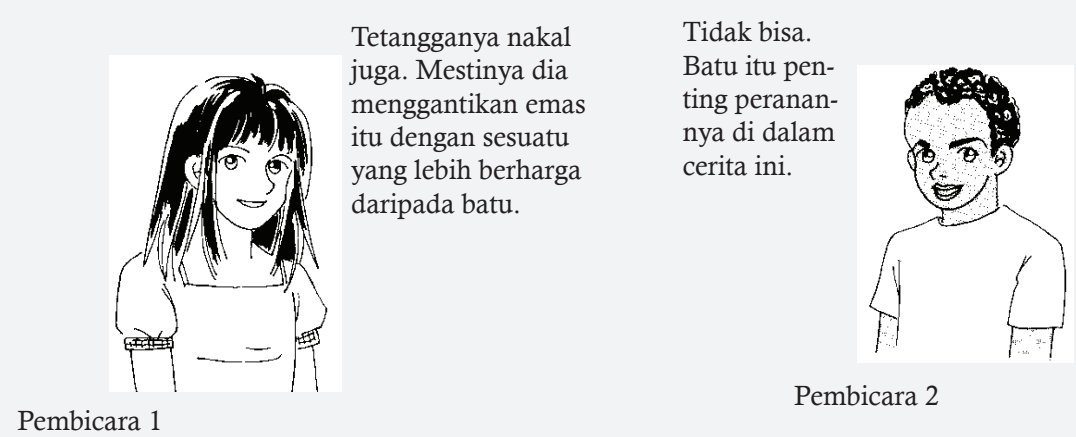

Apa yang dapat dikatakan Pembicara 2 untuk mendukung pendapatnya? 
Ketiga, Tipe tingkat berpikir pada contoh soal nomor 6 adalah kemampuan merefleksikan dan mengevaluasi isi bacaan. Pembaca membuat hipotesis alasan perbuatan pelaku cerita dengan menggabungkan informasi sebelumnya dengan informasi pada bacaan serta informasi di luar teks, seperti contoh soal berikut ini.

Mengapa si kikir mengubur emasnya?

Kempat, tipe pertanyaan mengintegrasikan dan menginterpretasikan: membentuk pemahaman yang luas, seperti contoh soal berikut ini.

Apa pesan utama cerita ini?

A. Jangan menyimpan kekayaan yang mudah dicuri.

B. Mempercayai orang lain adalah suatu kesalahan.

C. Tidak menggunakan apa yang dimiliki sama dengan tidak memilikinya.

D. Jangan menangisi sesuatu yang tidak bisa diubah.

\section{Karakteristik Soal Literasi Membaca PISA Berdasarkan Ragam Soal}

Karakteristik soal membaca pada PISA ditinjau dari segi ragam tes dan penyajian soal dipaparkan berikut. Ragam tes yang digunakan pada soal membaca PISA adalah pilihan ganda, pilihan ganda kompleks, jawaban singkat, esai tertutup, dan esai terbuka. Ragam tes tersebut disajikan ber- variasi berdasarkan sebuah teks yang mendahuluinya. Sebuah teks dikembangkan menjadi tes pilihan ganda, pilihan ganda kompleks, tes esai terbuka, dan esai tertutup. Soal esai dan objektif tidak dikelompokkan sendiri tetapi berselang-seling digunakan pada pada semua teks. Karakteristik tersebut dapat dilihat pada soal membaca berikut.

Bacalah teks berikut kemudian jawablah pertanyaan-pertanyaan di bawah ini!

KEAMANAN TELEPON GENGGAM (HP)

Ide Utama

Berbagai laporan yang

saling bertentangan tentang

resiko kesehatan HP

muncul pada akhir tahun

1990an.
Apakah HP berbahaya?

Ya

1. Gelombang radio yang dikeluarkan HP dapat meningkatkan panas sel tubuh, yang menimbulkan dampak yang membahayakan.

2. Medan magnet yang ditimbulkan HP dapat mempengaruhi cara kerja sel-sel tubuh.

3. Orang-orang yang berbicara lama dengan HP kadang-kadang mengeluh kelelahan, sakit kepala, dan kehilangan konsentrasi.

\section{Tidak}

Gelombang radio tidak cukup kuat untuk dapat menyebabkan peningkatan suhu tubuh yang membahayakan.

Medan magnet kekuatannya sangat kecil, sehingga tidak mungkin dapat mempengaruhi sel-sel di dalam tubuh kita.

Pengaruh-pengaruh seperti ini belum pernah diobservasi secara teliti dan mungkin saja hal ini disebabkan oleh faktor-faktor lain dalam gaya hidup modern. 
Ya

4. Pengguna HP memiliki kemungkinan terkena penyakit kanker di daerah otak yang berdekatan dengan telinga yang digunakan untuk menelepon 2,5 kali lipat lebih besar daripada bukan pengguna HP.

Milyaran rupiah telah dikeluarkan dalam penelitian ilmiah untuk meneliti dampak HP.
Ide Utama

Mengingat banyaknya

pengguna HP, efek sekecil

apapun yang terjadi pada

kesehatan dapat memiliki

implikasi yang luas terhadap

kesehatan masyarakat.
5. Organisasi Internasional untuk Penelitian di Bidang Kanker menemukan hubungan antara penyakit kanker pada anak-anak dengan kabel tegangan tinggi listrik. Seperti halnya HP, kabel tegangan tinggi listrik juga mengeluarkan radiasi.

6. Gelombang frekuensi radio sama dengan gelombang dari HP mengubah gen cacing tambang.

\section{Tidak}

Para peneliti mengakui bahwa meningkatnya kemungkinan terkena kanker ini belum tentu berhubungan dengan penggunaan HP.

Radiasi yang dikeluarkan oleh kabel listrik adalah jenis radiasi yang berbeda, dengan energi yang lebih besar daripada yang dikeluarkan oleh HP.

Cacing tambang bukanlah manusia, sehingga tidak ada jaminan bahwa sel otak kita akan bereaksi dengan cara yang sama.

Jika kamu menggunakan HP ...

Bila dalam keadaan siap dari tubuh kamu.

Belilah HP dengan "waktu bicara" yang lama. Hal ini lebih efisien, dan memiliki emisi yang lebih rendah. pakai jauhkan posisi HP

Selalu berbicara sesingkat mungkin.

Keterangan: SAR (specific absorption rate) adalah suatu ukuran yang menunjukkan seberapa besar radiasi yang diserap oleh sel tubuh manusia sewaktu menggunakan HP

Pertama, bentuk tes pilihan ganda dengan tujuan mengukur kemampuan merefleksikan dan mengevaluasi bacaan serta mengenal hubungan antara pernyataan yang diberikan di luar isi bacaan yang ada di dalam tabel dengan pernyataan yang ada di dalam tabel. Perhatikan contoh soal berikut ini.

\section{Lihat Tabel Apakah HP berbahaya?}

Apa maksud pernyataan di dalam kolom Tidak?

A. Untuk menggambarkan keuntungan menggunakan HP.

B. Untuk menggambarkan kerugian menggunakan HP.

C. Untuk menjelaskan mengapa HP berbahaya.

D. Untuk menentang pernyataan bahwa HP berbahaya. 
Kedua, bentuk tes esai terbuka dengan mengukur kemampuan merefleksikan dan mengevaluasi isi bacaan. Perhatikan contoh soal berikut ini.

Perhatikan poin 3 pada kolom Tidak pada tabel. Dalam konteks ini, kira-kira apa yang menjadi salah satu faktor dari "faktor-faktor lain" tersebut? Berikan alasan untuk jawabanmu.

Ketiga, bentuk tes pilihan ganda kompleks dengan mengukur kemampuan merfleksikan dan mengevaluasi kasus merupakan contoh terapan dari isi bacaan atau bukan contoh.

Perhatikan pernyataan berikut ini: "Hasil penelitian dari satu situasi tidak selalu berlaku pada situasi yang berbeda."

Coba tunjukkan apakah masing-masing pernyataan pada kolom Tidak di bawah ini merupakan contoh yang tepat untuk pernyataan di atas atau tidak.

Jawaban untuk tugas pertama diberikan di bawah ini sebagai contoh.

Tidak

1. Gelombang radio tidak cukup kuat untuk dapat menyebabkan peningkatan suhu tubuh yang membahayakan.

2. Para peneliti mengakui bahwa meningkatnya kemungkinan terkena kanker ini belum tentu berhubungan dengan penggunaan HP.

3. Radiasi yang dikeluarkan oleh kabel tegangan tinggi listrik adalah jenis radiasi yang berbeda, dengan energi yang lebih besar daripada yang dikeluarkan oleh HP.

4. Cacing tambang bukanlah manusia, sehingga tidak ada jaminan bahwa sel otak kita akan bereaksi dengan cara yang sama.
"Hasil penelitian dari satu situasi tidak selalu berlaku pada situasi yang berbeda."

$\begin{array}{ll}\begin{array}{l}\text { Merupakan } \\ \text { contoh }\end{array} & \begin{array}{l}\text { Tidak merupakan } \\ \text { contoh }\end{array} \\ \begin{array}{l}\text { Merupakan } \\ \text { contoh }\end{array} & \begin{array}{l}\text { Tidak merupakan } \\ \text { contoh }\end{array}\end{array}$

Merupakan

Tidak merupakan

contoh contoh

Merupakan

contoh

Tidak merupakan contoh

Keempat, bentuk tes pilihan ganda dengan mengukur kemampuan menginterpretasi dan mengintegrasikan secara luas

Perhatikan tabel dengan judul Jika kamu menggunakan HP ...

Di antara pernyataan berikut, yang manakah yang merupakan dasar ide yang terdapat pada tabel tersebut?

A. Tidak ada bahaya yang ditimbulkan oleh penggunaan HP.

B. Terdapat bukti yang menunjukkan adanya bahaya menggunakan HP.

C. Mungkin ada dan mungkin juga tidak ada bahaya menggunakan HP, tetapi ada baiknya untuk tetap berhati-hati.

D. Mungkin ada dan mungkin juga tidak ada bahaya menggunakan HP, tetapi sebaiknya jangan memakai HP dulu sebelum mengetahui secara yakin.

E. Pernyataan yang ada pada kolom Harus adalah bagi kelompok orang yang menganggap serius bahaya HP, dan pernyataan pada kolom Jangan adalah bagi kelompok lainnya. 
Kelima, bentuk tes pilihan ganda dengan mengukur kemampuan menginterpretasi dan mengintegrasikan secara luas.

Apa maksud yang terkandung di dalam Ide Utama?

A. Memaparkan bahaya menggunakan HP.

B. Menyampaikan bahwa perdebatan mengenai keamanan HP masih berlangsung.

C. Memaparkan tindakan-tindakan pencegahan yang harus dilakukan oleh para pemakai HP.

D. Menyampaikan bahwa tidak ada persoalan kesehatan yang ditimbulkan oleh HP.

Karakteristik Soal Membaca PISA dari Aspek Kebahasaan yang Digunakan

Ditinjau dari penggunaan kalimat, soal membaca PISA menggunakan wacana dengan kalimat-kalimat kompleks. Jumlah kata berkisar 135 sampai 610 kata. Pada wacana nonkontinyus (tabel, diagram, grafik) cenderung menggunakan beberapa variabel dan simbol yang rumit. Peta/ denah/ tabel atau grafik cenderung bersifat kompleks dan berkaitan dengan bagian yang lain. Contoh karakteristik penggunaan wacana yang berupa tabel rumit dicontohkan berikut.

\section{DANAU CHAD}

Gambar 1 Menunjukkan kedalaman yang berubah-ubah dari Danau Chad di Gurun Sahara, Afrika Utara. Danau Chad menghilang sama sekali pada kira-kira 20.000 sebelum Masehi, selama zaman Es. Pada kira-kira 11.000 SM danau itu kembali muncul. Sekarang kedalamannya kira-kira sama dengan kedalaman pada tahun $1000 \mathrm{M}$.

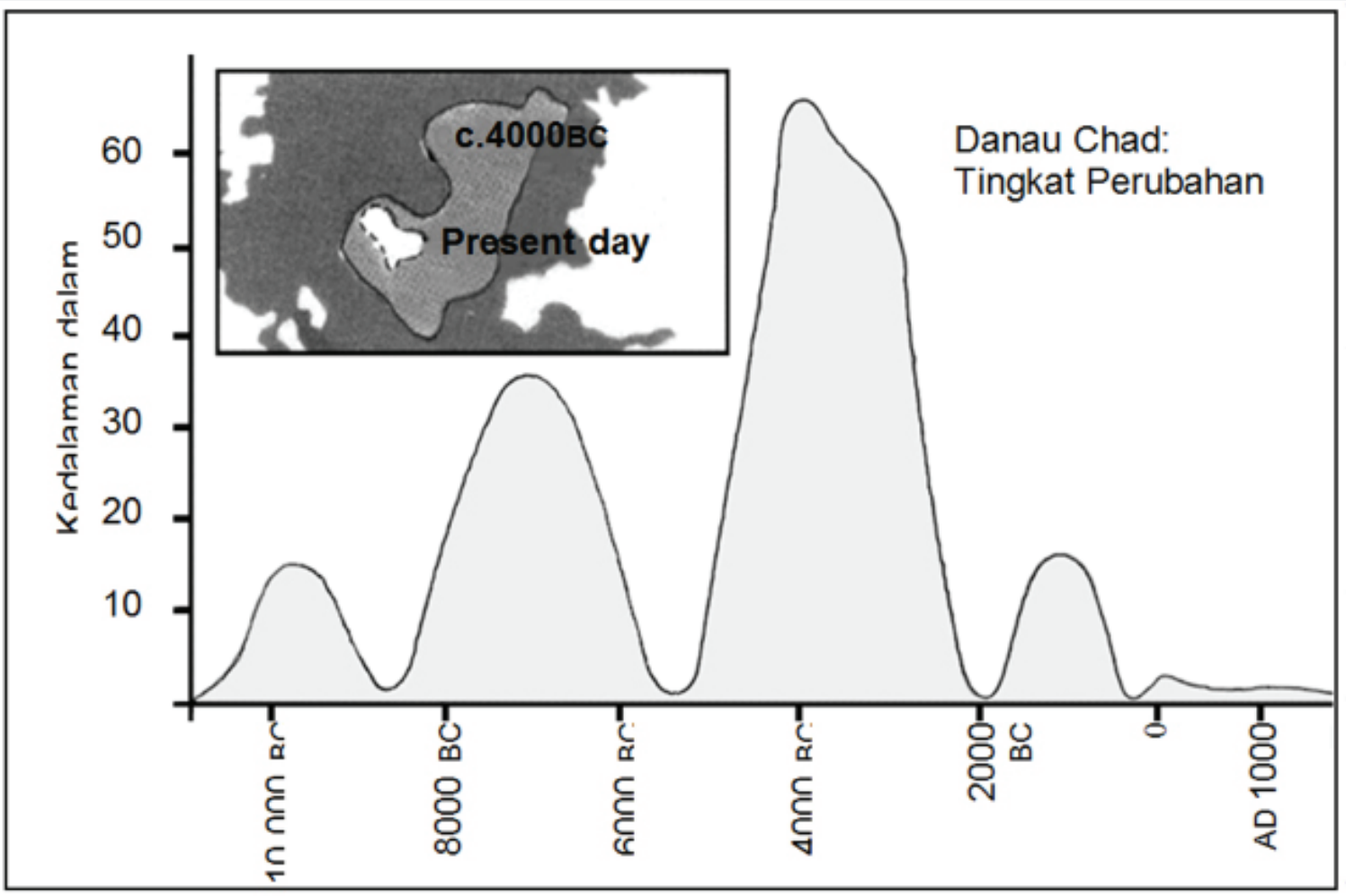


Gambar 2 Menunjukkan seni batu Sahara (gambaran atau kuno yang ditemukan pada dinding-dinding gua) dan perubahan pola hidup binatang buas.

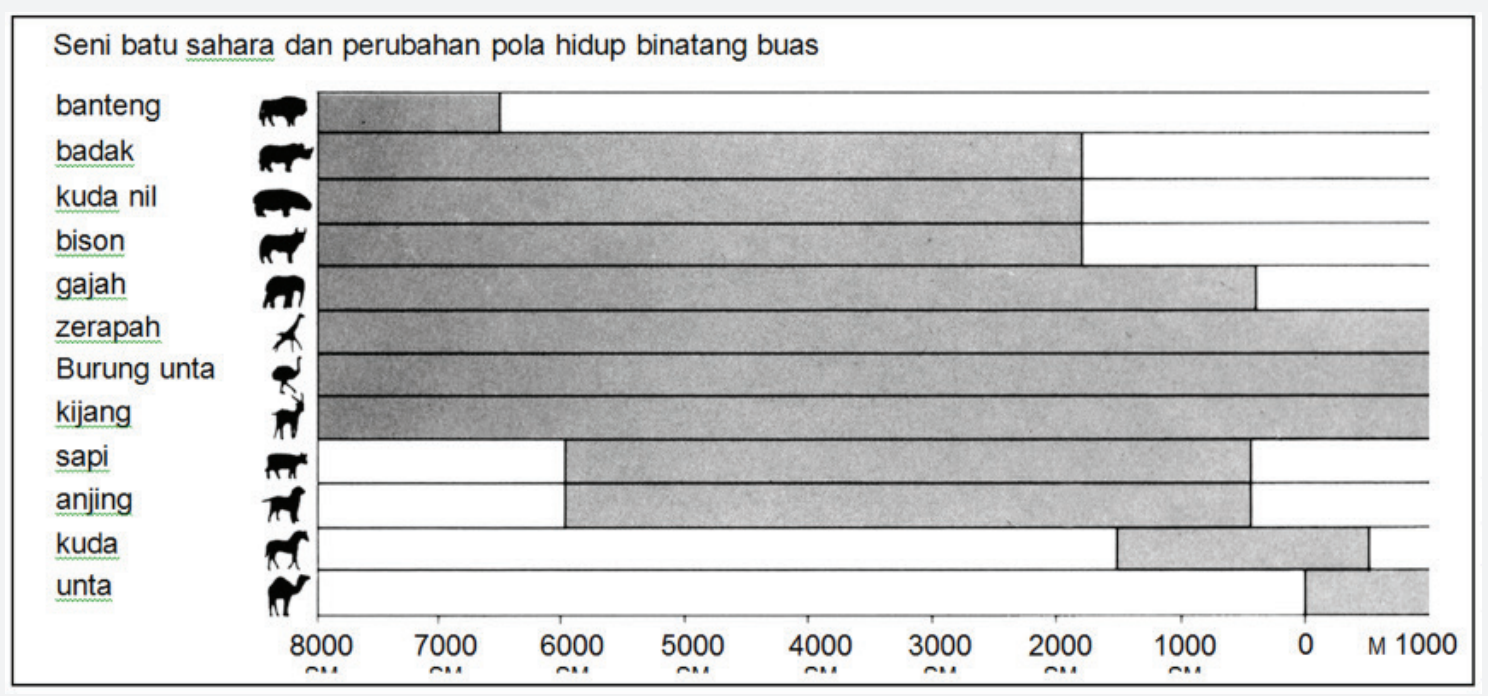

Gunakan informasi tentang Danau Chad tersebut untuk menjawab pertanyaan-pertanyaan berikut. Berapakah kedalaman Danau Chad sekarang?
A. Sekitar dua meter.
B. Sekitar lima belas meter
C. Sekitar lima puluh meter
D. Danau itu telah hilang sama sekali.
E. Tak ada informasi tentang itu.

Kira-kira tahun berapa grafik pada gambar 1 dimulai?

Mengapa penulis memulai grafiknya pada titik tersebut?

Gambar 2 didasarkan pada pandangan bahwa:

A. binatang-binatang pada seni batu terdapat pada daerah tersebut pada saat digambar.

B. para seniman yang menggambar binatang-binatang itu sangat terampil.

C. para seniman yang menggambar binatang-binatang itu dapat ber pergian jauh.

D. tidak ada usaha menjinakkan binatang-binatang yang digambarkan pada seni batu tersebut.

Untuk pertanyaan ini, kamu harus dapat menggabungkan informasi dari gambar 1 dan gambar 2.

Menghilangnya badak, kuda nil, dan bison dari seni batu Sahara terjadi
A. pada awal Zaman Es yang terbaru.
B. pada pertengahan periode saat Danau Chad berada pada tingkat kedalaman tertinggi.
C. setelah dasar Danau Chad menurun selama lebih dari seribu tahun.
D. pada permulaan periode kering yang terus menerus. 


\section{Karakteristik Isi dan Konteks Kutipan pada Soal PISA}

PISA bertujuan mengukur sejauh mana pendidikan dasar di suatu negara mampu menyiapkan siswanya untuk menghadapi dunia nyata, menggapai pengetahuan yang lebih tinggi, bersosialisasi di kancah global, dan memenuhi kebutuhan dasar/keterampilan hidup siswa siswa. Dengan tujuan tersebut, konteks kutipan memiliki karakteristik isi yang khas. Karakteristik konteks isi kutipan soal membaca PISA diringkas pada tabel berikut.

Tabel 1 Karakteristik Konteks, Tujuan, dan Isi pada Soal PISA

\begin{tabular}{|c|c|c|}
\hline Konteks & Tema/ isi kutipan & Tujuan \\
\hline $\begin{array}{l}\text { Konteks pendidikan, pekerjaan, } \\
\text { personal, masyarakat pada } \\
\text { wacana kontinyus (paparan } \\
\text { paragraf) }\end{array}$ & $\begin{array}{l}\text { Cara mengikuti pertukaran } \\
\text { pelajar, keamanan bahaya } \\
\text { penggunaan HP, penggunaan, } \\
\text { cara dan rasional menggosok } \\
\text { gigi yang benar, memilih baju } \\
\text { yang tepat, memilih sepatu yang } \\
\text { tepat, cara dan rasional memilih } \\
\text { makanan di supermarket, cara } \\
\text { menghindari iklan obral yang } \\
\text { berlebihan, memilih nilai-nilai } \\
\text { moral untuk mencintai profesi, } \\
\text { memilih nilai-nilai moral untuk } \\
\text { menjalani hidup dengan bahagia }\end{array}$ & $\begin{array}{l}\text { Meningkatkan keterampilan } \\
\text { hidup dalam mengakses dan } \\
\text { memanfaatkan informasi } \\
\text { berupa wacana untuk } \\
\text { menjalani kehidupan dalam } \\
\text { konteks pendidikan, } \\
\text { pekerjaan, keselamatan, dan } \\
\text { keamanan diri }\end{array}$ \\
\hline $\begin{array}{l}\text { Konteks pendidikan, pekerjaan, } \\
\text { personal, masyarakat pada } \\
\text { wacana nonkontinyus (berupa } \\
\text { tabel, grafik, bagan, denah } \\
\text { formulir) }\end{array}$ & $\begin{array}{l}\text { Orientasi denah kendaraan } \\
\text { umum, denah perpustakaan, } \\
\text { cara mencapai suatu tempat } \\
\text { penting, cara mengisi tabel/ } \\
\text { angket pada survei, memahami } \\
\text { grafik hasil survei tentang } \\
\text { kebutuhan hidup, memahami } \\
\text { dan mengisi formulir }\end{array}$ & $\begin{array}{l}\text { Meningkatkan keterampilan } \\
\text { hidup mengakses dan } \\
\text { memanfaatkan informasi } \\
\text { berupa denah, peta, tabel, } \\
\text { formulir dan grafik untuk } \\
\text { menjalani kehidupan dalam } \\
\text { konteks pendidikan, } \\
\text { pekerjaan, keselamatan dan } \\
\text { keamanan diri }\end{array}$ \\
\hline
\end{tabular}

Dari tabel 1 dapat disimpulkan bahwa karakteristik konteks pada soal PISA dapat diklasifikasikan pada konteks pendidikan, pekerjaan, personal, dan masyarakat. Isi kutipan pada soal membaca PISA dipilih dengan tujuan meningkatkan keterampilan hidup dalam mengakses dan memanfaatkan informasi berupa wacana untuk menjalani kehidupan dalam masyarakat, pendidikan, pekerjaan, dan personal. Secara rinci persentasi konteks pada soal membaca PISA dipaparkan berikut. 
Tabel 2 Distribusi Soal Membaca Berdasar Konteks dan Tipe Butir PISA

\begin{tabular}{llllllll}
\hline \multirow{2}{*}{ Konteks bacaan } & MC & $\begin{array}{l}\text { MC } \\
\text { kompleks }\end{array}$ & $\begin{array}{l}\text { CR } \\
\text { Tertutup }\end{array}$ & $\begin{array}{l}\text { CR } \\
\text { Terbuka }\end{array}$ & $\begin{array}{l}\text { Jawaban } \\
\text { singkat }\end{array}$ & Total & Persentase \\
\hline Pendidikan & 22 & 4 & 1 & 4 & 5 & 36 & $27,27 \%$ \\
Pekerjaan & 4 & 1 & 4 & 9 & 4 & 22 & $16,66 \%$ \\
Personal & 10 & & 3 & 10 & 3 & 26 & $19,69 \%$ \\
Masyarakat & 18 & 1 & 7 & 17 & 5 & 48 & $36,36 \%$ \\
Total & 54 & 6 & 15 & 40 & 17 & 132 & $100 \%$ \\
\hline
\end{tabular}

Dari tabel 2 dapat disimpulkan bahwa soal membaca PISA sebagian besar menggunakan konteks masyarakat (36,36\%). Disusul berturut-turut konteks pendidikan (27,27\%), konteks personal $(19,69 \%)$, dan konteks pekerjaan $(16,66 \%)$.

\section{Karakteristik Soal Membaca PISA 2003 dan 2006 sebagai Bahan Uji Minor}

Pada tahun 2003 dan 2006 soal literasi membaca menjadi bahan uji minor. Bahan uji mayor pada PISA 2003 dan 2006 adalah soal Sains dan Matematika. Pada tahun 2003 dan 2006 soal literasi membaca menjadi unsur minor. Karakteristik soal literasi membaca sebagai bahan uji minor pada tahun 2003 dan 2006 diringkas pada tabel 3.

Tabel 3 Distribusi Soal Membaca Berdasarkan Kompetensi dan Tipe Soal pada PISA dengan Membaca sebagai Bahan Uji Minor

\begin{tabular}{lcccc}
\hline Format butir soal & $\begin{array}{c}\text { Jumlah } \\
\text { Butir }\end{array}$ & $\begin{array}{c}\text { Menggali } \\
\text { informasi }\end{array}$ & $\begin{array}{c}\text { Mengintegrasikan dan } \\
\text { menginterpretasi bacaan }\end{array}$ & $\begin{array}{c}\text { Merefleksi dan } \\
\text { mengevaluasi }\end{array}$ \\
\hline Pilihan Ganda & 9 & 0 & 9 & 0 \\
Pilihan Ganda & 1 & 1 & 0 & 0 \\
Kompleks & 7 & 6 & 1 & 0 \\
Respon tertutup & 14 & 3 & 4 & 7 \\
Esai terbuka & 31 & 10 & 14 & 7 \\
Jumlah & $100 \%$ & $32,25 \%$ & $45,16 \%$ & $22,58 \%$ \\
Persentasi & & & & \\
\hline
\end{tabular}

Dari tabel 3 dapat disimpulkan bahwa pada soal membaca PISA sebagai bahan uji minor (PISA 2003 dan 2006) persentasi tingkat berpikir tinggi mendominasi yaitu sebesar 67,74\%. Kemampuan berpikir tingkat tinggi pada soal membaca PISA mencakup kemampuan mengintegrasikan, menginterpretasi, merefleksi, dan mengevaluasi. Kemampuan menemukan kembali informasi sebagai kemampuan membaca yang lebih mudah memiliki persentasi persentasi sebesar 32, 25\%. 
Tabel 4 Distribusi Butir Membaca Berdasarkan Ragam Teks pada PISA sebagai bahan Uji Minor

\begin{tabular}{lccccc}
\hline Jenis bacaan & $\begin{array}{c}\text { Jumlah } \\
\text { Butir }\end{array}$ & $\begin{array}{c}\text { Menggali } \\
\text { informasi }\end{array}$ & $\begin{array}{c}\text { Menginterpretasi } \\
\text { bacaan }\end{array}$ & $\begin{array}{c}\text { Refleksi dan } \\
\text { evaluasi }\end{array}$ & Persentasi \\
\hline Narasi & 3 & 0 & 1 & 2 & $9,67 \%$ \\
Eksposisi & 12 & 0 & 9 & 3 & $38,70 \%$ \\
Argumentasi & 6 & 4 & 1 & 1 & $19,35 \%$ \\
Bagan dan grafik & 2 & 1 & 1 & 0 & $6,45 \%$ \\
Tabel & 4 & 3 & 1 & 0 & $12,90 \%$ \\
Peta/ denah & 1 & 1 & 0 & 0 & $3,22 \%$ \\
Formulir & 3 & 1 & 1 & 1 & $9,67 \%$ \\
Total & 31 & 10 & 14 & 7 & \\
\hline
\end{tabular}

Dari Tabel 4 dapat disimpulkan bahwa pada soal membaca PISA sebagai bahan uji minor (PISA 2003 dan 2006) persentasi ragam teks bacaan tertinggi adalah jenis teks eksposisi (38,70\%). Ragam kutipan argumentasi yang digunakan pada soal PISA sebesar $19,35 \%$, tabel sebesar $12,90 \%$, narasi $9,67 \%$, formulir $9,67 \%$, bagan/ grafik $6,45 \%$, dan kutipan tabel sebesar $12,90 \%$.

\section{Karakteristik Butir Membaca sebagai Bahan Uji Mayor pada PISA 2000 dan 2009}

Butir tes yang digunakan pada soal membaca PISA sebagai bahan uji mayor berjumlah 131 butir. PISA 2000 dan 2009 adalah siklus PISA yang berfokus pada kemampuan membaca sedangkan Sains dan Matematika sebagai bahan uji minor. Distribusi karakteristik soal membaca PISA 2009 dapat dilihat pada tabel berikut.

Tabel 5 Distribusi Soal Membaca Berdasarkan Kompetensi dan Tipe Soal pada PISA dengan Membaca sebagai Bahan Uji Mayor

\begin{tabular}{lcccc}
\hline & $\begin{array}{c}\text { Penemuan } \\
\text { informasi }\end{array}$ & $\begin{array}{c}\text { Integrasi dan } \\
\text { interpretasi }\end{array}$ & $\begin{array}{c}\text { Refleksi dan } \\
\text { evaluasi }\end{array}$ & Total \\
\hline Pilihan Ganda & 6 & 38 & 8 & $52(40 \%)$ \\
Pilihan Ganda & 3 & 6 & 1 & $10(8 \%)$ \\
Kompleks & 9 & 4 & 0 & $13(10 \%)$ \\
Respon tertutup & 10 & 1 & 0 & $11(8 \%)$ \\
Jawaban Singkat & 3 & 18 & 24 & $45(34 \%)$ \\
Respon Terbuka & $31(24 \%)$ & $67(51 \%)$ & $33(25 \%)$ & $131(100 \%)$ \\
Total & & & & \\
\hline
\end{tabular}


Dari tabel 5 dapat disimpulkan bahwa pada soal membaca PISA sebagai bahan uji mayor (PISA 2000 dan 2009) persentasi tingkat berpikir tinggi mendominasi yaitu sebesar $76 \%$. Kemampuan berpikir tingkat tinggi pada soal membaca PISA mencakup kemampuan mengintegrasikan, menginterpretasi, merefleksi, dan mengevaluasi. Kemampuan menemukan kembali informasi sebagai kemampuan membaca yang lebih mudah memiliki persentasi persentasi sebesar $24 \%$.

Tabel 6 Distribusi Butir Membaca Berdasar Proses dan Jenis Bacaan pada PISA 2009 dan 2000

\begin{tabular}{lcccc}
\hline & $\begin{array}{c}\text { Penemuan } \\
\text { informasi }\end{array}$ & $\begin{array}{c}\text { Integrasi dan } \\
\text { interpretasi }\end{array}$ & $\begin{array}{c}\text { Refleksi dan } \\
\text { evaluasi }\end{array}$ & Total \\
\hline Argumentasi & 5 & 16 & 9 & $30(23 \%)$ \\
Eksposisi & 8 & 23 & 9 & $40(31 \%)$ \\
Deskripsi & 6 & 1 & 4 & $11(8 \%)$ \\
\hline
\end{tabular}

\begin{tabular}{lcccc}
\hline Narasi & 2 & 16 & 2 & $20(15 \%)$ \\
$\begin{array}{l}\text { Grafik, tabel, } \\
\text { denah, formulir }\end{array}$ & 10 & 11 & 9 & $30(23 \%)$ \\
Total & $31(24 \%)$ & $67(51 \%)$ & $33(25 \%)$ & $131(100 \%)$ \\
\hline
\end{tabular}

Dari tabel 6 dapat disimpulkan bahwa pada soal membaca PISA sebagai bahan uji mayor (PISA 2000 dan 2009) persentasi ragam teks bacaan tertinggi adalah jenis teks eksposisi (31\%). Ragam kutipan argumentasi yang digunakan pada soal PISA sebesar $23 \%$, narasi $15 \%$, dan tabel/ grafik/ denah/ formulir sebesar $23 \%$.

\section{PEMBAHASAN}

Dari hasil penelitian Balitbang (2011) tentang Trend Kemampuan Literasi Membaca Siswa Indonesia pada PISA ditemukan bahwa kemampuan literasi membaca siswa Indonesia masih di bawah rata-rata kemampuan membaca siswa internasional. Kemmapuan membaca siswa Indonesia juga baru berada pada level 2 dari 6 level yang ditentukan. Dengan temuan penelitian ini dapat dikaitkan bahwa rendahnya kemampuan membaca pada asesmen inter- nasional PISA terkait dengan jenis kemampuan berpikir tingkat tinggi yang mendominasi soal membaca PISA. Jumlah soal berpikir tingkat tinggi $76 \%$ pada $2000 /$ 2009 , dan $67 \%$ pada tahun $2003 / 2006$. Kesulitan siswa Indonesia dalam memahami soal PISA juga dapat dipahami dengan adanya temuan pada penelitian ini yaitu karakteristik tiap teks yang relatif panjang yaitu sejumlah 135-630 kata dan variabel grafik/ tabel/ bagan yang cenderung kompleks. Apalagi jumlah soal pada PISA 2000 dan 2009 sebesar 131. Ketahanan membaca siswa Indonesia yang masih rendah menyebabkan kesulitan yang lebih kompleks lagi. Kesulitan siswa Indonesia dalam membaca juga dapat dikaitkan dengan hasil penelitian ini dari segi penggunaan bahasa pada soal membaca PISA. Hasil analisis menunjukkan bahwa masih terdapat penggunaan campur kode 
bahasa Indonesia dan bahasa Inggris. Hal ini disebabkan adanya aturan bahwa soal membaca PISA diterima dalam bahasa Inggris dan harus diterjemahkan ke dalam Bahasa Nasional tiap-tiap negara. Soalsoal literasi membaca PISA yang diterjemahkan dari Bahasa Inggris ke dalam Bahasa Indonesia tetap menggunakan latar cerita dan latar budaya Barat dan kurang dipahami siswa. Skemata budaya siswa Indonesia kurang relevan sehingga sulit memahami soal PISA yang sebagain besar bersifat interpretasi, integrasi, refleksi, dan evalausi. Berdasarkan penelitian Matsuda (2005) pemahaman skemata budaya dapat meningkatkan pemahaman inferensial siswa. Latar budaya minat baca yang tinggi pada tempat soal PISA dibuat menyebabkan pilihan teks cenderung dengan jumlah kata yang banyak dan simbol yang rumit. Peta/ denah/ tabel atau grafik cenderung bersifat kompleks dan berkaitan dengan bagian yang lain. Kecermatan dan kekritisan siswa yang kurang akan menyebabkan rendahnya pemahaman soal PISA.

Dari hasil analisis ditemukan bahwa soal membaca PISA didominasi oleh keterampilan berpikir tingkat tinggi yaitu kemampuan menginterpretasi, mengintegrasikan, merefleksikan, dan mengevaluasi isi teks. Temuan dalam penelitian ini memberikan penjelasan alasan rendahnya kemampuan literasi membaca siswa Indonesia pada PISA mulai tahun 2000-2009. Rendahnya kemampuan literasi membaca PISA selama empat kali pelaksanaan dapat dipahami karena soal membaca PISA didominasi keterampilan berpikir tingkat tinggi. Hal ini sejajar dengan hasil penelitian kuantitatif Trend Soal literasi Membaca PISA yang menemukan bahwa kesulitan siswa Indonesia mencakup (a) pertanyaan evalua- tif terhadap isi dengan kriteria internal dan memberi alasan, (b) pertanyaani evaluasi berbentuk esai terbatas maupun jawaban singkat, (c) kemampuan mengungkapkan alasan dengan bukti pada isi teks, dan (d) pertanyaan tentang sikap dan strategi penulis.

Standar Isi Bahasa Indonesia SMP dan pembelajaran membaca perlu menyesuaikan dengan karakteristik tingkat berpikir tingkat tinggi pada soal membaca PISA sebagi brenchmark internasional anak usia 15 tahun (lulus SMP). Standar Isi Bahasa Indonesia perlu memberikan porsi besar pada keterampilan membaca tingkat tinggi dalam berbagai konteks. Kemampuan merefleksikan dan mengevaluasi isi teks merupakan keterampilan paling sulit dibandingkan keterampilan mengungkapkan kembali informasi. Peningkatan rata-rata kemampuan membaca secara internasional dapat difasilitasi dengan peningkatan pembelajaran kemampuan reflektif. Implementasi pembelajaran keterampilan berpikir tingkat tinggi secara maksimal dan perancangan yang fokus pada Standar Isi bisa memfasilitasi peningkatan literasi membaca pada perspektif internasional.

Di samping itu, pencapaian hasil literasi membaca yang masih di bawah ratarata kemampuan internasional dimungkinkan karena ketahanan membaca yang masih rendah dari siswa Indonesia. Hasil itu sejalan dengan penelitian Suryaman (2015), tentang analisis hasil belajar peserta didik dalam literasi membaca melalui Studi Internasional (PIRLS) 2011. Hal ini dibuktikan dengan hasil penelitian ini yang menuntut ketahanan membaca maksimal untuk dapat mengerjakan soal membaca PISA dengan teks yang panjang-panjang dan mengintegrasikan berbagai teks (multiteks). 


\section{SIMPULAN}

Dari segi aspek kompetensi membaca yang diukur, soal literasi membaca PISA memiliki karakteristik berfokus pada kemampuan membaca tingkat tinggi. Secara kuantitatif kemampuan membaca jenis interpretasi, refleksi, dan evaluasi sebesar $76 \%$. Pada soal membaca PISA jenis kompetensi membaca diklasifikasikanmenjadi tiga kelompok yaitu: (a) kemampuan mengungkapkan kembali informasi (retrieving Information), (b) mengembangkan interpretasi (developing an interpretation), dan (c) merefleksikan/ mengevaluasi teks. Tingkat berpikir tingkat tinggi menjadi porsi utama pada keseluruhan soal membaca PISA dari tahun 2000 sampai 2009. Kemampuan berpikir tingkat tinggi mencakup kemampuan mengembangkan interpretasi, kemampuan merefleksi, dan kemampuan mengevaluasi teks.

Dari segi penggunaan bahasa, soal membaca PISA masih terdapat penggunaan campur kode bahasa Indonesia dan bahasa Inggris. Hal ini disebabkan adanya aturan PISA bahwa soal membaca diterima dalam bahasa Inggris dan harus diterjemahkan ke dalam Bahasa Nasional tiap-tiap negara. Dari bentuk kalimat dan jumlah katanya, soal membaca PISA cenderung menggunakan wacana yang panjang dengan jumlah kata 135-600 kata. Kalimat pertanyaan cenderung kompleks.

Ragam tes yang digunakan pada soal membaca PISA adalah pilihan ganda, pilihan ganda kompleks, jawaban singkat, esai tertutup, dan esai terbuka. Ragam tes tersebut disajikan bervariasi berdasarkan sebuah teks yang mendahuluinya. Sebuah teks dikembangkan menjadi tes pilihan ganda, pilihan ganda kompleks, tes esai terbuka, dan esai tertutup. Satu teks diberi soal esai dan objektif secara berselang-seling dengan berbagai jenis tingkatan berpikir.

Karakteristik konteks pada soal PISA dapat diklasifikasikan menjadi empat kategori yaitu konteks pendidikan pekerjaan, personal, dan masyarakat. Isi kutipan pada soal membaca PISA dipilih dengan tujuan meningkatkan keterampilan hidup mengakses dan memanfaatkan informasi berupa wacana untuk menjalani kehidupan dalam masyarakat dan menjaga keselamatan/ keamanan diri. Soal membaca PISA sebagian besar menggunakan konteks masyarakat $(36,36 \%)$. Disusul berturut-turut konteks pendidikan $(27,27 \%)$, konteks personal $(19,69 \%)$, dan konteks pekerjaan $(16,66 \%)$.

Karakteristik soal membaca PISA sebagai bahan uji minor (PISA 2003 dan 2006) dapat ditinjau dari jumlah soal, persentasi tingkat berpikir, dan persentasi ragam teks yang digunakan. Pada soal membaca PISA sebagai bahan uji minor (PISA 2003 dan 2006) jumlah soal 31 butir yang didominasi kemampuan berpikir tingkat tinggi yaitu sebesar $67,74 \%$. Kemampuan berpikir tingkat tinggi pada soal membaca PISA mencakup kemampuan mengintegrasikan, menginterpretasi, merefleksi, dan mengevaluasi. Kemampuan menemukan kembali informasi sebagai kemampuan membaca yang lebih mudah memiliki persentasi persentasi sebesar 32, 25\%. Dari segi ragam teks kutipan, soal membaca PISA sebagai bahan uji minor (PISA 2003 dan 2006) menggunakan ragam teks bacaan terbanyak jenis teks eksposisi $(38,70 \%)$. Ragam kutipan argumentasi yang digunakan pada soal PISA sebagai bahan uji minor sebesar 19,35\%, tabel sebesar $12,90 \%$, narasi $9,67 \%$, formulir $9,67 \%$, bagan/ grafik $6,45 \%$, dan kutipan tabel 
sebesar $12,90 \%$.

Karakteristik soal membaca PISA sebagai bahan uji mayor (PISA 2000 dan 2009) dapat ditinjau dari jumlah soal, persentasi tingkat berpikir, dan persentasi ragam teks yang digunakan. Pada soal membaca PISA sebagai bahan uji mayor (PISA 2000 dan 2009) jumlah soal 131 butir yang didominasi kemampuan berpikir tingkat tinggi yaitu sebesar $76 \%$. Kemampuan berpikir tingkat tinggi pada soal membaca PISA mencakup kemampuan mengintegrasikan, menginterpretasi, merefleksi, dan mengevaluasi. Kemampuan menemukan kembali informasi sebagai kemampuan membaca yang lebih mudah memiliki persentasi persentasi sebesar $24 \%$. Dari segi ragam teks, soal membaca PISA sebagai bahan uji mayor (PISA 2000 dan 2009) menggunakan ragam teks bacaan tertinggi jenis teks eksposisi yaitu sebesar 31\%. Ragam kutipan argumentasi yang digunakan pada soal PISA sebesar 23\%, narasi 15\%, dan tabel/ grafik/ denah/ formulir sebesar $23 \%$.

\section{UCAPAN TERIMA KASIH}

Ucapan terima kasih disampaikan kepada teman sejawat yang telah memberi masukan dalam proses penelitian. Ucapan terima kasih disampaikan juga kepada reviewer yang telah memberi masukan untuk perbaikan artikel ini.

\section{DAFTAR PUSTAKA}

Alderson, Charles. 2000. Assessing Reading. London: Cambridge University Press. Frank, B. May. Reading as Communication an Interactive Approach. Columbus: Merrill Publishing, 1990.
Departemen Pendidikan dan Kebudayaan Nasional. Trend Kemampuan Literasi Membaca pada PISA 2000-2009. Balitbang: Pusat Penilaian Pendidikan Departemen Pendidikan Nasiona. 2004. Membaca untuk Pengembangan Berpikir Kritis-kreatif Siswa SMP. Jakarta: Proyek Guru Sekolah Menengah.

Hayat, Bahrul. Kemampuan Dasar Hidup: Prestasi Literasi Membaca Anak Indonesia Usia 15 Tahun di Dunia Internasional. Jakarta: Pusat Penilaian Pendidikan, 2006.

Hirai, Debra L. Cook, Irene Borrego dan Emilio Garza, dan Carl T. 2009. Klock. Literacy Strategies for Adolesents: How to Manual for Educator. New York: Routledge Taylor \& Francis Group, 2009.

OECD 2000. Frame Work Programme International Students Assessment. Paris: OECD.

OECD 2003. Frame Work Programme International Students Assessment. Paris: OECD.

OECD 2006. Frame Work Programme International Students Assessment. Paris: OECD.

OECD 2009. Programme International Students Assessmen. Assessment Framework: Key Competencies in Reading, Mathematics, and Science. Paris: OECD.

Krippendorff, Klaus. Analisis Isi. Jakarta: PT. Raja Grafindo Persada, 1993.

Sevilla, Consuelo dan Gabriel G. Uriarte. 2001. Pengantar Metode Penelitian. Jakarta: UI Press

Suryaman, M. 2015. "Analisis Hasil Belajar Peserta Didik dalam Literasi membaca melalui Studi Internasional (PIRLS) 2011". Litera, Vol. 14, No. 1. 